\title{
Correction to: Experimental Study of Thermoelectric Cooler Box Using Heat Sink with Vapor Chamber as Hot Side Cooling Device
}

Adi Winarta, I. Made Rasta, I. Nyoman Suamir, and I. G. K. Puja

\section{Correction to:}

Chapter "Experimental Study of Thermoelectric Cooler Box Using Heat Sink with Vapor Chamber as Hot Side Cooling Device" in: Akhyar (ed.), Proceedings of the 2nd International Conference on Experimental and Computational Mechanics in Engineering, Lecture Notes in Mechanical Engineering, https://doi.org/10.1007/978-981-16-0736-3_37

The chapter "Experimental Study of Thermoelectric Cooler 15 Box Using Heat Sink with Vapor Chamber as Hot Side Cooling Device" was published with an incorrect Acknowledgement text, which has now been corrected in the chapter. 